\title{
Andrey Rubliov \\ El camino espiritual del artista en un periodo de transición y crueldad.
}

El film o "kartina", del director ruso Tarkovsky, es una obra maestra. La integración perfecta entre formas visuales y contenido abre la secuencia de imágenes a múltiples significados y provoca profundas experiencias éticas y estéticas. El espectador puede contemplar las alternancias con secuencias de franjas de oscuridad, penumbra, planos iluminados y deleitarse con el virtuosismo formal del director y el director de fotografía. La contemplación de la estructura narrativa que comienza con escenas de la cultura popular de los vagabundos rusos campesinos y termina con el triunfo del improvisado fundidor de campanas, en una afirmación del poder de la nueva creencia religiosa que da paso al hallazgo de sí mismo por parte del monje Andrey Rubliov. Esta contemplación de la maestría compositiva del director a lo mejor sea suficiente.

Sin embargo, el film presenta una multiplicidad de temas y cuestiones que provocan la imaginación del espectador. Se trata de una película que es al mismo tiempo la narración
Rubén Dario Flórez Arcila Profesor de Semiótica Universidad Nacional rubendarioflorez@gmail.com sobre las fuerzas interiores que se disputan el alma del principal protagonista pero es también la interpretación no ortodoxa del director, acerca de los resortes interiores que impulsan las acciones de las fuerzas y sujetos representados en la película. La belleza espiritual del paisaje, de los cuerpos, de las miradas, de los objetos y los animales más cotidianos, traen a la mente del espectador la idea de un mundo animado por poderosas fuerzas espirituales en lucha con la ambición del dominio. Pero esta dominación, de manera paradójica, origina un impulso de creación de belleza con capacidad de transformación ética e interior.

\section{El cristianismo.}

El pintor de íconos Andrey Rubliov, es mostrado durante el transcurso de los casi últimos veintitrés años de sú vida. No es un personaje de ficción. Vivió en la Rusia Medieval entre 1360 y 1430. Pintó las catedrales del Kremlin y de Vladimir-, cuyo templo ocupa un lugar central al comienzo 
de la película. La historia muestra los años de búsqueda de sí mismo por el pintor monje errante en medio de la violencia. Tres grandes conflictos son mostrados: la lucha del poder de los príncipes rusos que han abrazado la religión cristiana oriental como religión estatal, contra las creencias paganas. El combate entre los tártaros y los mismos príncipes rusos por el dominio político y finalmente la estrategia de la iglesia ortodoxa por erradicar las costumbres y las creencias paganas del pueblo raso. En esta época la religión es instrumento político de control brutal, como cuando los enviados del zar arrancan con un puñal los ojos a los artesanos pintores ayudantes de Rubliov, que han incumplido el contrato de pintar los frescos de la catedral. Aunque se trata de la imposición de nuevas creencias, el director muestra el conflicto de Rubliov. Se niega a pintar escenas que atemoricen. El tiene una interpretación particular del cristianismo. Podría decirse que él establece una simbiosis entre el júbilo del amor pagano que lo marcó durante la noche que vivió los extraños ritos y la orgía de primavera, con su propia interpretación del amor cristiano. Si tengo sabiduría y no tengo amor, nada valgo. La decisión de no pintar un juicio final madura en él después de la noche en el bosque. Allí vivió la experiencia de un amor físico en profunda conexión con los ritos colectivos al inicio de la primavera.

A través de Rubliov, Tarkovsky propone una vivencia del cristianismo, como acciones con otros, religados a través del dolor y la experiencia de la belleza como irradiación de la armonia que se alcanza a través de un camino de fracasos. A diferencia de los filmes occidentales los sujetos están vinculados entre ellos por medio de acciones físicas y espirituales. Los objetos no existen como mediadores entre ellos.
El director se detiene en los movimientos de los cuerpos, en su plasticidad, en los sentidos intangibles que crean las miradas y su comunicación extrema.

El cristianismo de Rubliov, es un cristianismo que cuestiona la erudición y la sabiduría de los letrados "Las personas de libros son falsas". Lo acompañan siempre jóvenes aprendices sin muchas letras, una mujer que parece estúpida, el artesano que lo impulsa a pintar es un joven que obedece a su propio instinto espiritual y a su sentido innato de la materia. La gran revelación sobre el amor carnal y espiritual o pagano se la proporciona una mujer de pocas palabras.

Esta espiritualidad encarnada en lo simple; esta belleza de los sencillos y elementales impregna la estructura formal, que consigue sin perderla un solo momento, una capacidad de expresión deslumbrante.

\section{Los protagonistas.}

En la historia se cuentan las historias de personajes que ingresarán unos minutos a la narración o permanecerán. Aunque el cristianismo es divulgado por personas letradas, aquí se trata de monjes con un modo de vida casi vagabundo. Los monjes pintores que permanecian en monasterios, llevan una existencia errante. Son tan pobres como los campesinos, juglares y aprendices vagabundos. Este modo de vida señala a un tipo de cultura popular. Se mezclan en ella creencias paganas y fragmentos de las escrituras. Andrey Rubliov tiene su mente y sus emociones influidas por las lecturas del Eclesiastés, algunos de cuyos fragmentos sabe de memoria. Aunque siempre están acompañados de amigos monjes y de vagabundos, cada uno conserva una individualidad. Nadie está solo, aunque como 
en el caso de Rubliov y el joven artesano de campanas atraviesen por crisis espirituales que los atormentan. Tal vez aquí el director muestre un vínculo afectivo arraigado con la cultura popular y con este cristianismo medieval.

Los protagonistas están impulsados por móviles espirituales definidos. Los vagabundos defienden sus ritos paganos. Los monjes pintores discuten el sentido de su oficio. Los guerreros tienen la pasión del dominio y de la guerra. Los artesanos y pintores de íconos están dispuestos hasta las últimas consecuencias por hallar su imagen interior que convertirán en un fresco o en una campana. El sentimiento de pecado como responsabilidad por los otros está presente como una poderosa fuerza que se transmuta en amor para liberarse de la pesadilla de la crueldad.

\section{El paisaje como imagen espiritual y física}

Tarkovsky posee el genio para convertir las imágenes del agua, de los ríos y de la lluvia en valores con una expresividad plástica, simbólica y espiritual. La lluvia puede ser signo de meditación, es decir transmite la controversia interior de sus personajes. Pero la lluvia diluye el paisaje en una especie de transparencia subjetiva. La lluvia difumina los contornos y convierte las escenas en una suerte de sueño que comparte el director con sus espectadores. Esto tiene que ver con la idea del director de fuerzas espirituales como potencias que impulsan a sus personajes. La belleza, el mal entendido como el ánima del pecado, la envidia, la compasión y la vida interior que se manifiesta en las acciones con otros.

Pero el director evita las abstracciones. Aún cuando sus personajes estén movidos por impulsos místicos o sencillamente estén desgarrados por conflictos espirituales tiene buen cuidado en afirmar la materialidad de la belleza del mundo. El vuelo en el globo que le muestra al piloto de las nubes el templo, mirándolo desde el ojo de Dios concluye estrellándose contra la ribera del río. Cuando el monje Rubliov recita como fuera de sí los versículos del Eclesiastés, la hija del príncipe le lanza a la cara un chorro de leche.

La tierra, el agua, el fuego y el aire participan con su belleza y con una presencia espiritual en las escenas de la película. Son como presencias que vienen de las antiguas creencias paganas de la cultura medieval rusa antes de la cristianización. Pero ellas están animadas el agua de los gigantescos ríos rusos, las lluvias de la primavera y la greda de los yacimientos para elaborar la forma de la campana, de la espiritualidad mistica y a la vez pagana.

\section{Los símbolos}

Son aquellos sitios de la cultura religiosa, popular y pagana, construcciones o lugares que comunican ideas o establecen vínculos con las acciones de los personajes.

Los gigantescos ríos rusos siempre en perspectiva desde el aire, a través de las ventanas están como espejos reflejando el cielo. Se les ve desde las torres de las iglesias o se ven en el horizonte como enigmáticos signos del sueño poético del director.

El abedul, árbol que emblematiza el paisaje ruso. Los templos recientemente construidos y que son el lugar de reunión de los nuevos creyentes. A su vez desde alli se difunde el conocimiento de los evangelios. Transmiten una condición nueva para el paisaje ruso. Han sido elegidos los sitios de su emplazamiento en colinas al borde de los ríos, señalando lugares estratégicos en las ciudades y en las estepas. 
Los caballos. Hacen parte del folklore ruso. Tarkovsky hace uso de su fuerza plástica para otorgarle realismo poético a las escenas en las que se discuten temas religiosos. Funcionan como puentes entre el mundo del sueño, del misticismo del pintor de íconos y el mundo de la vida. Pero más que caballos son signos del lenguaje del director que enfatiza el movimiento del paisaje.

Conflictos u oposiciones de temas y personajes La primera oposición estructural es la del color. El film se desenvuelve en blanco y negro. Al final de repente se muestra un segmento de cinco minutos en color. Simboliza el hallazgo del pintor de iconos de su condición de maestro espiritual y de la culminación de su búsqueda. Logra plasmar en los colores de los íconos pintados sobre madera su propia comprensión de la espiritualidad cristiana.

Hay una oposición o contraste, que es una clave de comprensión de las ideas de Rubliov. El joven que ignora los secretos del arte de fundir campanas impulsado por el deseo de celebridad, con una ambición sin erudición funde la campana que culmina la búsqueda de Rubliov. A partir de alli el monje pintor encuentra dentro de sí las fuerzas y la voluntad para pintar lo que le ha costado una vida de búsqueda. Es la oposición entre el conocimiento y la intuición.

Las creencias se oponen. Los cristianos se enfrentan a los paganos. Los emisarios del príncipe destruyen los instrumentos, las costumbres y las creencias de los campesinos rusos. Pero los tártaros invasores se burlan de las creencias de los cristianos: ¿Cómo puede ser virgen María si dio a luz a un niño? Profanan los templos ortodoxos.

\section{Estructura formal del film}

El genio del director se manifiesta en el virtuosismo para estructurar en oposiciones de arriba y abajo los espacios de la película. En el aspecto cromático exhibe un total dominio de las posibilidades expresivas de los contrastes de claroscuros, sombras, penumbras tenebrosas, iluminación deslumbrante y transiciones de la oscuridad a las franjas lóbregas o tenuemente iluminadas. Esto transmite emociones y estados de ánimo luego de un conflicto o previo al enfrentamiento de fuerzas interiores. La maestría de Tarkovsky consiste en que estas oposiciones y contrastes nunca son un puro juego formal.

El espectador a veces "mira" desde adentro, junto con los personajes, a través de las hendiduras y ventanas que constantemente muestran el paisaje y anticipan las acciones que vendrán. Esto permite al espectador tener una especie de intimidad visual y apreciar el carácter de experiencia onírica de la narración cinematográfica.

\section{Sonidos.}

El espectador redescubre los sonidos básicos. Los de la lluvia, la madera, las voces de los vagabundos, los cantos y voces emitidos por los animales y los pájaros. El chapoteo sobre la greda de la lluvia. Esta música elemental subraya el carácter esencial y espiritual de la pelicula. Es la precisión en los detalles de la vida cotidiana en el medioevo ruso. ¿Cuándo no había tecnología como la que hoy hace parte de nuestra vida, cuáles eran los sonidos habituales para el oído? En la película la respuesta a esta pregunta le da un realismo poético a las escenas, como si esta precisión del director de elegir sonidos básicos, el trote de los caballos, los sonidos secos de la madera, el chirriar de la plata fundiéndose, el sonido quebrado de las puertas, el silbar del 
viento y el canto de la lluvia nos transmitiera el mensaje de unos personajes orgánicamente vinculados con los elementos del paisaje. Pero este paisaje tiene una calidad espiritual. Es el hombre con sus acciones que implican una búsqueda mística y estética, el que convierte los elementos y las cosas en signos que hablan de su alma.

\section{El camino del pintor vagabundo.}

El camino del pintor Rubliov hasta Vladimir, lo hice en el año de 1982, con tres amigos poetas, Sasha Kyldyshev de la ciudad de Kostramá en el norte de Rusia, Alexei que conocia la historia de las iglesias de Moscú y Dimitri que había hecho la peregrinación hasta el kremlin de Vladimir. Tomamos el tren desde Moscú que salia hasta la ciudad de la iglesia donde Rubliov pintó sus frescos en los años que narra la película. Éramos entonces estudiantes de literatura vagabundos. El tren salió a las ocho de la mañana. Iba avanzando por la gigantesca planicie rusa. En muchos sitios por donde íbamos atravesando, el bosque de coniferas no había cambiado mayor cosa. Podría tener el mismo aspecto del bosque en donde para el equinoccio de verano se celebraban los ritos paganos. En una de las estaciones se subió un hombre viejo que cubria la cabeza con capuchón negro. Apenas empezaba el otoño y el campo ruso ofrecía la alquimia de colores básicos que se ven en los iconos de Rubliov al final de la película. Poco después en otra estación subió una mujer que me llamó la atención. La plenitud sensual de formas que cubria con una bata de algodón tosco, la hacia ver más misteriosa pero carnal. Aunque fueron observaciones mias de actos fugaces, entre muchos otros que sucedieron dentro del tren. Sasha Kyldyshev, llevaba un libro viejo de antes de la revolución con grabados de los iconos que empezaban a descubrir los artistas rusos de la vanguardia. El hombre del capuchón negro se aproximó hasta nosotros. Tenía barba larga y canosa. Lo acompañaba la mujer que entró unos minutos después. Ahora los dos parecía que se conocieran muy bien. Nos preguntó de dónde habiamos sacado el libro. -"Vamos a Vladimir para ver los frescos de Rubliov"- Respondí. - "Ah", dijo., "el amor físico es un amor místico". Y se quedó callado. La mujer le tomó la mano y lo miró largo tiempo. Después los dos salieron en la siguiente estación del tren, desde donde se veia un gigantesco bosque. Alexei nos dijo que parecian, la mujer y el hombre del capuchón negro, sectarios de una vieja herejía perseguida desde el medioevo que había sobrevivido a la revolución. El camino hasta el templo de Vladimir como en los tiempos de Rubliov, seguía siendo recorrido por vagabundos que buscaban una transformación.

Cuando Rubliov comienza su camino será testigo de masacres. Verá como la violencia se ensaña con las creencias que socavan el prestigio de la nueva religión estatal. Pero también padecerá cuando a sus discípulos les arrancan los ojos. Se sentirá culpable. Se rebelará sin violencia frente a las formas institucionales y a las imágenes oficiales de la nueva religión cristiana ortodoxa. Mientras él se debate en una pregunta esencial, ¿cuál es el tema que debe pintar?, los enviados del príncipe castigarán a sus súbditos. Rubliov que como un humilde vagabundo recorre el territorio entre Moscú y Vladimir verá también la profanación del templo cuyas paredes ha pintado. Se verá obligado a matar contrariando su principio de hermandad. Tendrá oídos y corazón para la locura de la Dúrochka, la mujer pobre de espíritu que lo acompañará. Es un hombre que no se encuentra y que ve a su alrededor crueldad y guerras temibles. Pero guardará en su interior el ánimo para pintar lo que quiere legar. Es un vagabundo como otros 
que ha visto destrucciones y muerte, cuya memoria conserva unos cuantos versículos del Eclesiastés en los que se cuestiona el conocimiento libresco y se reitera la idea de la vida como un tránsito. El vagabundo podrá hacer de su camino a través de la guerra una metamorfosis espiritual. Al final un joven campanero simple le enseñará que el amor puede servirse aún de los medios más humildes para crear y formar un vinculo. Las penumbras, lo blanco y lo oscuro, la greda, las raices y el ritmo del cuerpo con sus memorias pueden ser medios sublimes. Que es el espiritu encarnado en el arte, sea este el sonido de una campana o el color de los iconos, la gracia de los signos en los que se transforma el dolor.

Cuando llegamos a Vladimir en aquel lejano otoño de 1982, pudimos ver los frescos de Rubliov. Pasaron muchos años y tuve que atravesar muchas fronteras para comprender el camino de Rubliov. 